\title{
Darwin down but not out
}

The British government has withdrawn its bid to have Charles Darwin's home and the surrounding countryside designated a World Heritage Site, at the same time expressing strong concern over the way in which sites of scientific heritage are judged.

The decision follows an unfavourable evaluation of the Darwin bid by the International Council on Monuments and Sites (ICOMOS), which advises UNESCO's World Heritage Committee on aspects of cultural heritage. The government says that the evaluation, which has not been made public, questioned the integrity, authenticity and value of the proposed site.

In an open letter to the director of the World Heritage Committee, the UK's Department of Culture, Media and Sport described this assessment as "fundamentally flawed" with "serious weaknesses and omissions". But proposed sites have only one chance with the committee. Fearing the ICOMOS report might sway the decision, the government chose not to let the Darwin nomination go before the committee, which meets on 23 June in Christchurch, New Zealand, to decide on new sites (see 'Natural wonders'). A new Darwin proposal will be submitted in two years' time.

This year's 'Darwin at Downe' proposal sought to put a World Heritage ring around 1,000 hectares of countryside in and around the village of Downe on the outskirts of London. At its heart is Down House, Darwin's home from 1842 until his death in 1882. The surrounding landscape fed Darwin's mind as he wrote The Origin of Species and later works: he studied orchids at Downe Bank, found insectivorous plants on Keston Common and collected seeds for his experiments at Cudham School pond.

"I can't think of anything more important to do for the history of nineteenth-century science

\section{Natural wonders}

Few cultural sites of scientific renown achieve World Heritage status, but natural wonders of interest to science do a bit better. The World Conservation Union (IUCN), which advises the World Heritage Committee on natural sites that might merit its consideration, is recommending that the following be added to the World Heritage list at the committee's forthcoming meeting in Christchurch, New Zealand:

- Primaeval beech forests in the Carpathian mountains, in Slovakia and the Ukraine

- The South China karst, a distinctive rock formation

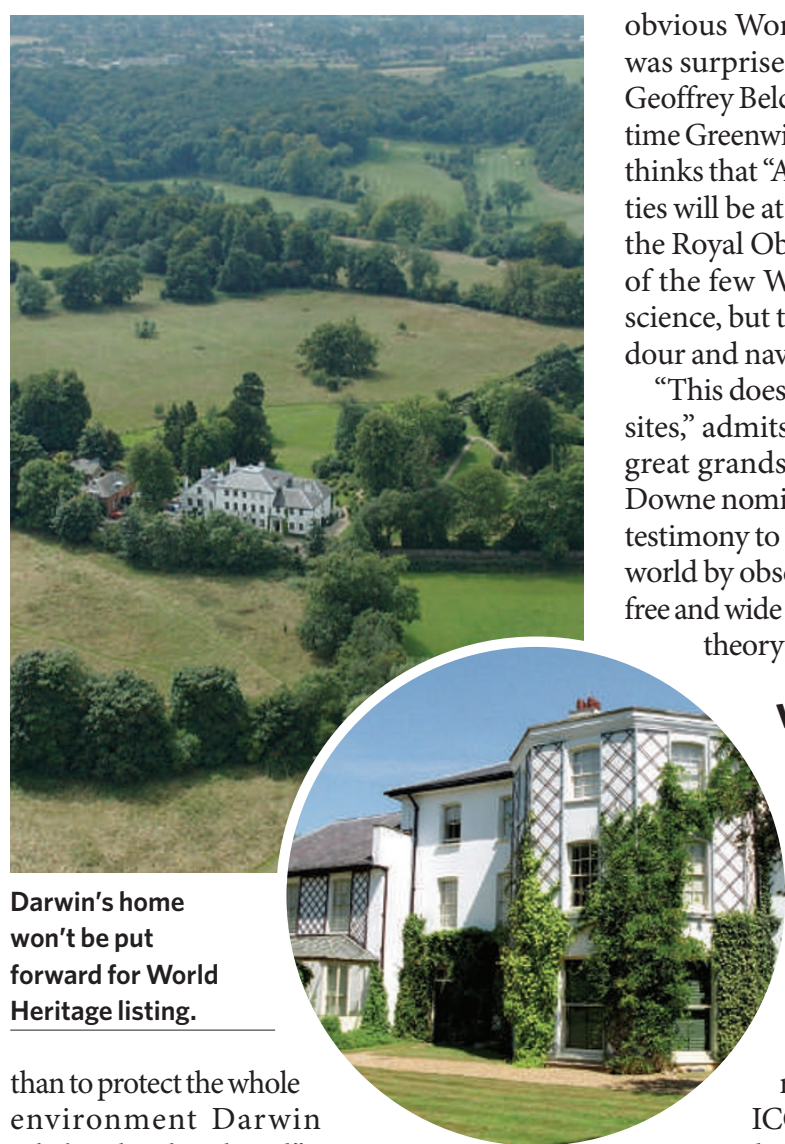

obvious World Heritage boxes. Although he was surprised to hear of Downe's difficulties, Geoffrey Belcher, site coordinator for the Maritime Greenwich World Heritage Site in London, "A site with a limited range of quali( theyal Observatory makes Greenwich one the few World Heritage Sites to celebrate our and naval history too.

“This doesn't look like other World Heritage sites," admits Randal Keynes, Darwin's greatgreat grandson and author of the Darwin at Downe nomination. But he defends its value as to "the understanding of the natural world by observation, hypothesis, experiment, wide exchange of information and ideas, eory-building and communication."

\section{Values in question}

In 2005 the World Heritage Committee called for "nominations which recognize and celebrate achievements in science", which seemed to make the Darwin at Downe proposal timely. But along with questioning the integrity of the landscape and the authenticity of the restoration of the house and gardens, the ICOMOS report argued that Downe inhabited and exploited," says

James Moore, a Darwin scholar at the Open University in Milton Keynes and one of the first historians to explore the importance of this rural refuge to Darwin. "Muslims go to Mecca, Christians go to Jerusalem, Darwinians go to Downe," he says.

But without natural wonders or spectacular architecture, Darwin at Downe does not tick

Jeju volcanic island and associated lava tubes, off the coast of South Korea

- The rainforests of Atsinanana, Madagascar, which contain much of the island's remaining biodiversity

- Teide National Park, Tenerife, Spain, which includes the peak of the world's third-tallest volcano (and an astronomical observatory) - Lope-Okanda, Gabon, a landscape boundary between tropical rainforest and relic savannah environments

The IUCN also recommends that the World Heritage Site centred around the Jungfrau in the Swiss Alps be expanded. and its surroundings are not of "outstanding universal value" as defined under the World Heritage Convention.

In its letter, the British government makes the broader point that few, if any, scientific sites will be accepted onto the World Heritage List unless a dedicated set of guidelines for their treatment is drawn up. It offers "to host and fund, on behalf of UNESCO, an international expert meeting to examine the issues of representing science on the World Heritage List." ICOMOS declined to comment on the letter.

Despite the setback, English Heritage, the government agency that has owned the Down House estate for the past decade, said it will go ahead with a new permanent exhibition, an education suite for school groups and a resources room where visitors can search the Down House collections, look at Darwin's Beagle notebooks online and learn more about his experiments. Culture minister David Lammy says that the government looks forward to submitting a revised bid in 2009, the bicentenary of Darwin's birth and the 150th anniversary of The Origin of Species.

Henry Nicholls 